\title{
$\begin{array}{llllllll}\mathbf{A} & \mathbf{R} & \mathbf{T} & \mathbf{Y} & \mathbf{K} & \mathbf{U} & \mathbf{E} & \mathbf{Y}\end{array}$
}

\section{STAROŻYTNA RODZINA GRECKA I RZYMSKA}

\section{Artykuł niniejszy ma przyjomnieć i przyblizyć zasalnicze wia-}

domości o rodzinie antycznej jako podstawowej konórce życia społecznego. Dowiadujemy sie o niej z zabytków kultury materialnej $i$ ze źródeł literackich ${ }^{1}$.

\section{Rodzina grecka}

Sceny z życia kobiet przedstawiane na freskacil pałaców kreteńskich 1 charakter religii dowodza, że kobiety miały na krecie wiz̨kszą swobodę i odgrywały większą rolę aniżell w czasach późniejszych w Grecj1 właściwej ${ }^{2}$. W wiekach XII-VIII nastąpił proces praejścia od ustroju rodowego do tzw. miasta-państwa . Plastyczny obraz rodziny tego okresu przekazał nam Homer ${ }^{3}$. Według niego miłość rządziła rodzinz. Tetyda z głębi morza słyszała płacz syna. Dusza matki odezwała się do Odysa w podziemiu. Słowa jej brzmia jak najpiękniejsza pochwała miłości synowskiej. Penelopa jest w tym samym stopniu bohaterką"Odysei" co jej mąź. Przez niego $i$ wim jest zawsze obecna. Myśl Odysa nigdy jej nie opuszcza. Myśli i sny żony są zawsze przy

1 Por. 0.Jurewicz - L.Winniczuk, Starożytni Grecy i llzymianie w źyciu prywatnym 1 państwowym, Warszawa 1970, 7-27/ilodzina/.

2 L.Winniczuk, Ludzie, zwyczaje, obyczaje starozytnej Grecji i Rzymu, Warszawa 1983, 199-261 / rodzinie greckiej i rzymskiej/; ii. Flacelière, Zycie codzienne w Grecji za czasów Peryklesa, tłum. Z.Bobowicz - J.TurgaIski, Warszawa 1985, 55-78 /Kobieta, małżénstwo, rodzina/.

3 Por. E.Mireaux, Życie codzienne w Grecji w epoce homeryckiej, tłum. z Pranc. S.Kołodziejczyk, Warszawa 1962, 160-178/Życie kobiet/. 
męzu $\mathbf{u}^{4}$.

Kobieta w czasach Homera była towarzyszką życia mężczyzny, niekiedy zajmowała pierwsze miejsce, jak Arete przy Alkonoosie. Męźcyzna szanował swa źonę, czcił matke, dawał posłuch głosow1 koblety. Kobieta brała udział w obrzędach religijnych 1 w ogólnym zyciu towarzyskim. Niewolnicy byl1 własnościa pana, zasiadali razem zanem do stołu 1 dzielili z nim jego troski.

W następstwie utworzenia Tó tylko wajedzinie życia państwowego, ale także rodzinnego. W poszczególnych lezałoby je rozpatrywać oddzielnie. Istniały jednak zasadnicze elementy wspólne dla całej Grecji. Wszędzie obowiazzywała monogamia oraz w całej niemal Grecji utrzymywał sie patriarchat, który przyznawał ojcu władze nieograniczoną nad dzlocmi. Władzę tę rozciaggaz nad tymi dzlećmi, które uznał za wasne 1 przyjaz do rodziny. Po uznaniu i przyjęciu dziecka nie mógł jeḍak rozporządzać jego zyc1em 1 molnościa.

W instytucji małzeństwa Grecy widzieli dwa cele: o charakterze państwowym i rodzinnym. Małzeństwo miało przysporzyć państwu obywateli dla przejacia po ojcach obowiazków wględem państwa, a więc mieli bronić granic kraju, zapewnic mu bezpieczeństwo i zapobiec jego wyludnieniu ${ }^{5}$. Potomstwo stanowiło przediuźenie rodu 1 rodziny, przejmowało obowiazki kultowe względem przodków w formie składania im ofiar oraz podtrzymywało tradycje rodzinne. Kodz1ce mieli tez w dzieciach oparcie na starość. Nieźonaci mężczýni narazali siobie na pozbawienie szacunku, fakim darzono ludzi zonatych 1 posiadających dzieci. Głownie w Sparcie bezzenność ' Yruí, pociagała za soba utratę czci, $\tau \iota \mu i r /$. Na uchylających sie od mazzenstwa nakładano nawet kare w postaci grzywny yocr y Zmuszano lch tez do biegania zimie nago po agorze 1 śpiewania piosenek, wtórych przyznawali się, że słusznie znosza upokorzenie. Prawo Likurga nakłontło Spartan do wybierania sobie zon z ro-

4 J.Parandowsk1, Wstep, W: Homer, Odyseja, tłum, 1 oprac... Warszawa 1964, 17 .

5 Thucydides, De bello Peloponnesiaco II 44-45, tłum. z grec. K.Kumaniecki/Tukydides, Wojna peloponeska, Warszawa 1953/, 111.

6 Pollucis Onomasticon VIII 40, Fasciculus posterior libros VI-X 
dzin niezaroźnych. Chciano w ten sposób zapobiec łączeniu 1 gromadzeniu wielkich majątkóm $w$ jednej rodzinie.

W weku VIII-VI ojciec dziewczyny decydowal o tym, kto mial zostac jej mężem. Według Herodota ${ }^{7}$ tyran Sykionu Klejstenes gościł u sieble przez cały rok 13 konkurentów, którzy ubiegali siez o jego córke Agaristę. W czasie samej gościny badał ich charakter. W tym celu urządzał dla nich wyścigl i zapasy. Wybrany na zięcia kandydat składał podarki $\varepsilon \delta \cup \alpha_{i}$ przyszłemu teściowi, a ten dawał młodej parze posag $/ \mu \varepsilon \imath \lambda_{\iota} \alpha /$, który wypadku rozwodu zięć by z zobowiązany zwrócić teściowi.

Y epoce klasycznej swoboda kobiet ateńskich, w porównaniu z okresem kreteńskim 1 mykeńskim, uległa znacznemu ograniczeniu. Kobieta była "pod mładza męzczyzny", najpierw ojca, w razie jego śmierci opiekuna, wreszcie męza. Nie miała zatem praw obywatelskich, ani teź nie mogła decydować o wasnych sprawach mająkowych. Życie kobiety ateńskiej $w$ dni powszednie ograniczało się do zajęć domowych 1 wychowania dzieci. Spędzała czas w swych pokojach yuv

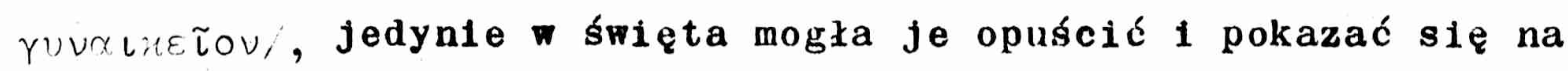
ulicy w towarzystwie niewolnicy, majac dyskretnie osłonięta twarz. Większymi swobodami cieszyły sie kobiety w Sparcie $i$ na wyspach. W tym okresie ojciec nadal decydował o wyborze męźa dla swej córki. Wybierał go spośród znanych soble młodych ludzi. Małżéstwo mogło być zawarte między obywatelem i córka wolnego obywatela danej

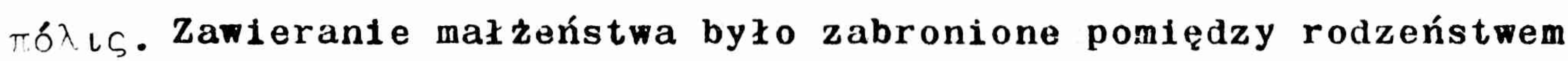
przyrodnim po tej samej matce/uterini/. Dziewczęta wydawano za mąz wieku 12 - 15 lat zycia. Według Platona moźna je wydawać za mąz dopiero wieku 16 - $201 a t^{8}$.

W epoce hellenistycznej kobiety cieszyły się większaz swobodą, mogły równtez zajmować siz własnym majłtkiem bez pomocy opiekuna. Coraz wi ̨cej kobiet zdobywało wykształcenie.

Zawarcie małzeństwa poprzedzały zaręczyny, Evúrclc, w czasie

continens. E codicibus ab ipso collatis denuo edidit et adnotavit E. Bethe, Lipsiae 1931, 118.

7 Ilerodotus, IIistoriae VI 126, tłun. z grec. S.Ilaumer /IIerodot, Dzieje, Warszawa 1954/, 443-446.

8 Plato, Leges VI 735B, tłur. z grec. M.llaykowska / ilaton, Prawa, Wargzawa 1960/ 272 . 
istórych ustalano warunki i wysokość posagu. Zaręczyny były umowa prawną między ojcem dziowczyny a narzeczonym. Jeżeli narzeczona nie miała ojca, to zastępował go jej brat, bliski krewny lub opiekun.

Zaślubiny miały począkowo charakter uroczystośc1 rodzinnej, pózniej nabrały mocy prawnej i zmieniły się w akt religijny. Porządek tych obrzędów był następujł̨cy: po kąpieli panny młodej w wodzie miejscowego źródła świętego i po uroczystym jej ubraniu, kiedy już przyszli zaproszeni goście, składano ofiary opiekuńczym bóstwom rodziny i. małzeństwa, tj. Dzeusowi, Herze, Hesti1, Artemidzie i Mojrom. Następnie ojciec przekazywał córke przyszłemu zięciowi, oświadczając przy tym, ze jest wolna od skladania ofiar swoim przodkom i że odtąd będzie składać ofiary przodkom mǫza. Wyzwolenie córki spod władzy ojca i przekazanie jej pod władzę męża stanowiło akt religijno-prawny zaślubin. Po tym akcie następowała uczta, w cza-

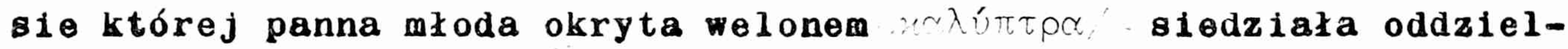
nie wraz ze swymi rómieśnicami. Po uczcio weselnej wieczorem odprowadzano uroczyócie nowożeńców z domu rodziców panny młodej do domu męa. Nowożeńcom towarzyszył ktoś z bliskich krewnych vúuolos/. Za nimi kroczył orszak weselny, śpiewając pieśni weselne tzw. hy-

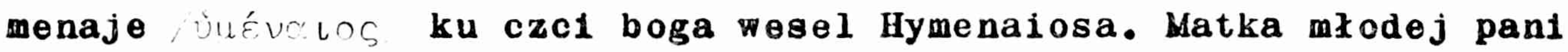
niosła pochodnte zapalona z ogniska domowego, by zapalić ognisko nowej rodziny, co podkreślało zwizzek obu rodzin oraz symbolizowazo wprowadzenie Hestil, bogini ogniska domowego, do domu nowozeńców. Pan młody przenosił na rekach swoja zonę przez próg domu. Uważa sie to za gest symboliczny, podkreslajacy stanowisko dziewczyny w jej nowym domu. Interpretujo sie tez ten fakt jako pozostałośc dawnych czasó, kiedy dziewczęta porymano. Thodzaca do domu nowa gospodynie obsypywano daktylami, ligami, orzechami, drobnym monetam1 tró, zyczono $j \otimes j$ wen sposób pomyślnośc1 1 zjodnyøano bogów domonych. Po czym rozniecano ogień na ognisku domomym. Małżonkowle zaś wspólne życłe rozpoczynali od złożenia oflar na ołtarzu domowym przodkom rodziny 1 od wspó Inogo posiłku składajacego slę z chleba i owocóm.

Po tych religijnych uroczystościach odbywała się uozta juz u młodych. Nowożeńcy otrzymymali od gości często cenno upominki. Uczta kończyła się odprowadzeniem młodej pary do małżeńskiej komna- 
ty/ $/ \alpha \lambda \alpha \mu \circ S_{\prime}^{\prime}$. Mzodziez, gdy veselo doblegazo końca, śpierała

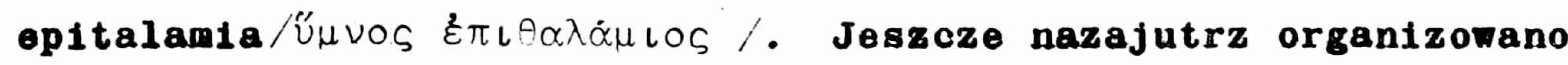
przyjecie. Ten ostatni dzień mesela nazywano anakalypteria l'́ $\vee \propto \varkappa \alpha \lambda \cup \pi \tau \varepsilon \rho \iota \alpha /$, poniewaz panna młoda mystęporała juz bez ślubnego welonu.

Po wesołych uroczystościach zaczynała sie codziennośc mazzeńskiego zycia, które nie zarsze układało sle pomý́lnie. Stąd już - Grecjl 1stniaza mozliwośc zerwania mazzeństwa. Dostatecznym powoder do rozwodu była zdrada ze strony zony. Mazz miaz prawo zabic jej kochanka. Platon potepia mszelka zdrade mazzerska ${ }^{9}$, ale $\boldsymbol{\text { prakty- }}$ co karana była jedynio zdrada zo strony zony. Platon przemiduje ponadto ustany, zmuszajace do rozwodu małzoństwa, które ciagu 10 lat

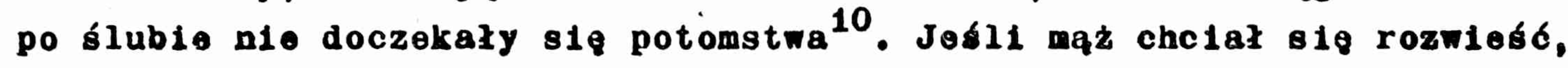
odsylaz zone wraz z posagiem do jej ojca lub opiekuna, nie podajac zadnych motywów rozwodu. Było to tzw. $\alpha \pi 0 \pi \circ u \pi n ́, \alpha \pi \delta \pi \varepsilon \mu(\iota \varsigma-$ odesłanie. Sprawa była bardziej złożona, gdy o rozwód prosiła zona. Musiała ona przedstawić archontow powody rozejścia sie na piśmie/CTó - opuszczenie/. Jeśli maź zgodził sie, sprawa była załatøiona; zie jednak sprzeciwu męza, rozstrzygano ja na drodze prawnej z odvozaniem $81 e$ do archonta. Filozofowie 1 prawodawcy przy rozwodzie wykazuja troske o stworzenie odpowiednich warunkó dla przyszłej matk1. Mieli oni na uradze główny cel małzeństwa, jakim było przeLazanie dzioci państwu ${ }^{11}$.

Przyjécle dziecka na śwlat było waznym wydarzeniem w zyciu rodzinnym. 0 uznaniu 1 przyjęciu go do rodziny decydowaz ojciec. W plątym lub szóstym dniu po urodzeniu potomka odbywała sie rodzinna uroczystość, zwana amphidromia /obieganie, obchodzenio dokoła/. ojcioc podnosit dziecko z ziemi, po czym obnoszono je dookola ogniska domorego, składano ofiary oczyszczalne 1 wreszcio 10 dniu po urodżeniu náawano mu imie. Polecano dziecko opiece bóstw domowych 1 Herze Elleityi, opiekunce urodzin. Do siódmego roku dziecko cho-

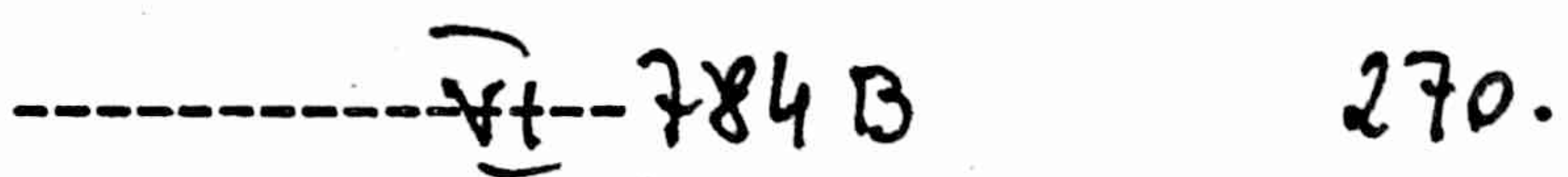

9 Tanze VII $840 D-B$, Maykorska 50z.

10 Tamżo VI 784B, Maykowska 270.

11 Tamze VI 783E I VII 792E, Maykorska 269 i 281. 
wało sie pod okiem matki 1 niewolnic domowych. Okros ten nazywaz

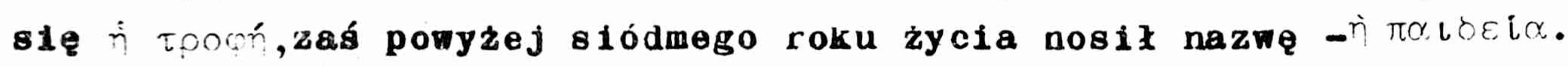
Plecze nad dzjeckien sprawowali rodzice. Jedynie wparcie istniazy tym zakresio osobne przepisy.

Straszny by los dzieci, których o.iciec nie przyjął do rodziny. Wyrzucano jo po prostu na śmietnik, co na ogół równało sie z wrokiem śmierci. Plutarch donosi, ze w Sparcie obowizzyało prawo natychmiastowego zabijania kalek ${ }^{12}$. ojciec po urodzeniu dziecka był obowiazany przedstawlé je starszym, którzy zaleźnie od wyniku badania fizycznego rozwoju niemowlecia decydowali o jego zyciu i dalszym wychowaniu, albo tez porzuceniu. G.Glotz utrzymuje, ze chodziło w tym przypadku o ograniczenie prawa do wychowania dziecka ${ }^{13}$. Szereg autoróm dopatruje się tym badaniu ograniczenia porzucania dzieci. G.Glotz ${ }^{14}$ E.Weiss ${ }^{15}$ twierdzę wręcz przeciwnio, że żadne z greckich miast, z wyjąkien Sparty i Teb, nie zabraniazo porzucania dzieci. W niektórych miastach, jak np. W Koryncie i Tebach, waadza ustawodawcza nawet uchwalała ustawy o ograniczeniu przyrostu ludności ${ }^{16}$. Porzucanie dzieci usankcjonowała w Grecji opinia publiczna, ktorej daja wyraz Platon i Arystoteles ${ }^{17}$, 1iteratura pięna 1 mitologia ${ }^{18}$. Inne $i$ całkiem odmienne spojrzenie na ten sar problem mial Polibiusz, opowiadajacy sie za wielodzietna rodzina ${ }^{19}$. Uczeni nie udowodnili, by $w$ pradawnych czasach greckich ojciec inial ius vitae necisque, wiadomo natomiast, że juź za rzádów Solona w 594 r. przed Chr. nie przyznano ojcu tego prawa. W ustawodawstwie greckim istniała możliwość publicznego wyrzeczenia sie swogo dziecka ńovelc - W ten sposób wyisluczano je z rodu oraz pozbawiano

12 Plutarchus, Vitae parallelae, Lycurgos 16, Recognovit C.Sintenis, Lipsiae 18'77, t.1, 97-y8.

13 G.Glotz, Expositio, DAGR II 937.

14 Tamże 930-931.

15 E.Weiss, Kinderaussetzung, itE 21, 1,464.

16 G.Glotz, Expositio, art.cyt., 939; L..Heiss, iinderaussetzung, art.cyt., $46:$

17. G.Glotz, ixpositio, art.cyt., 938; Aristoteles, politica II 3,7 i II 9,7, tłum. z grec. L.Piotrowicz/Arystoteles, Polityka, Hrockaw 1953/47 i 76 .

18 E.Weiss, Kinderaussetzung, art.cyt.,464; U. Wilamowitz-Noellendorfe, Staat und Gesellschaft der Giecher und sibmer, Leipzig-Berlin 1923, 35.

Polybius, Historiae XXXVII 9, tłum.z grec. S.Hammer - M.Brożek 
wszelkich praw. Od czasów Solona w Atenach 1 w innych państwach greckich istniał zakaz sprzedaży dzieci. Juź w V w. przed Chr. władze ojca nad dzieckiem az do jego pełnoletności określano ustama. Mimo tych danych, świadczacych o humanitaryzmie, problem porzucania i zabijania dzieci Grecji pozostaje faktem pownym 1 udowodnionym. Porzucanie dzieci, głównie dziewczynek, tłumaczono warunkami gospodarczymi kraju, które nie mogły zapewnić utrzymania większej liczbie mieszkańców. Stąd zrodziza się tendencja regulacj1 nie urodzeń, ale zaludnienia. Ograniczano więc liczbe dziecl do dwojga, rzadko spotykało sie w rodzinie troje dzioci, a wyjatkowo rodziny z dwiema córkami, poniewaz niżej ceniono wartośc s1ły roboczej dziewcząt. Nie broniły one tez granic, and nie sprawowały kultu przodków. Przeciwko zwyczajowi dzieciobójstwa wystąpil Filip v Macedoński po bitwie pod Kynoskefalai /197 r./. Obawiajac sie w przyszłości osłabienia armii, popierat rodziny wielodzietre.

Podsumowując zebrane wiadomości o starożytnej rodzinie greckiej można stwierdzić, ze składaza sie ona z ojca, matki, dzieci i niewolników. Ojciec rodziny był panem domu, fúplos, opiekunem 1 racanikiem rodziny wobec bogóm i ludzi. W imioniu całej rodzlny skádał on ofiary bogom, zastępował poszczególnych cźonkó rodziny w sadzie $i$ sprawach państwowych. Wadza ojca była patriarchalna, ale nie absolutna. Kobiete od majdawniejszych czasó zejmowała u wszystkich Grekóm zaszczytne w swym powolaniu odpowiednio stanowisko m rodzinie i społeczeństwie. Jako matka rodziny byla pania domu, kierowała domem, dawała polecenia niewolnikom, wychowyaka dzieci, byıa towarzyszka męa. Szanomana dom, lecz zyciu publicznym nie posiadała zadnych praw. W domu rodzinnym oplekunom jej by ojciec albo najstarszy brat, potem - maz, a razio wowieństwa - najstargzy pejnoletni ayn lub najbilzazy krewny. Kobloty greckie z zasady nie opuszczary gwej izby, z myjatkiem publicznych uroczystości. Dom by $1 \mathrm{ch}$ głónym polea pracy 1 oddziałyania.

\section{Rodzina rzymska}

Kodzina / Pamilia/ juz wasach najdawniejazych stanowia podstawe państra rzymskiogo. W jej skład wchodzili: ojclec i mack

/Polibiusz, Dzioje, t.2, Warszawa 1962/440-441. 
rodziny, synowe \& curki niezamężne, żony 1 dzieci synów, niewolnicy oraz córki męzatki, które zawarły małzeństwo bez przejścia pod władze męza. Istniały trzy możliwości wejścia do rodziny pod wadze ojca/conventio in manum patris familias/: przez urodzenie w prawnie uznanym małzeństwie i przyjecie dziecka do rodziny, przez przysposobienie/adoptio/, przy czym przysposobiony pozostawaz niezalezny /sui luris/ lub przechodzit pod waadze ojca rodziny /arrogatio/ oraz przez przejście synowej pod wadzę teścia.

Głowa rodziny był ojciec/pater familias/, tylko on pozostawał wodzinie prawnie od nikogo niezalezny/sui iuris/. Pozostali zaśs członkowie rodziny byli pod jego władza /alieno luri subiect1/. Mradza ojea była potrójna: wadza nad żona/manus/, władza nad dziecmi /patria potestas/, wadza nad niewolnikami/dominica potestas/. Wradza nad zona pypływała z małzeństwa. Dziewczyna wychodząc za mąz uwalniała się spod wadzy ojca lub opiekuna 1 wchodziła do rodziny męza, przyjmując nad soba jego wadze/conventio in manum/. nowej rodzinie posiadała prawa córki. Wobec dzieci miał ojcioc prawo zycia i śmierci/ius vitae ac necis/. Zdarzały sie wypadki zwalniania synów spod wadzy ojca/emancipatio/ albo przekazania waadzy nad nimi innemu obywatelow1 na zasadzie przysposobienia /adoptio/. Według Theodora Mommsena ani emancipatio, ani adoptio nie istniały juz za czasów królewskich ${ }^{20}$. Co sie tyczy wadzy nad niewolnikami, to według prawa rzymskiego nie uwazano ich za osoby, lecz za rzeczy/res mancipii/. Właściciel mógl według wzasnego upodobania rozporzłdzać praca, mieniem, życiem, potomstwem swego niewolnika, miał prawo go takze sprzedać, komu innemu przekazać, a nawet zabić. Niewolnicy nie mogli tez zawrzeć właściwego małzeństwa /matrimonium/, ale tylko prowadzić wspólne pożcie. Zdarzalo sie, ze waściciel wyzwolit niewolnika spod swej wadzy /manumissio/. Wtedy niewolnik przybierat nomen 1 praenomen swego pana 1 stawal sie jego klientem.

Według opini językoznawców wyrazy "pater" 1 "potestas", po-

20 Th.Mommsen, Romisches Staatsrecht, w: Landbuch der romisohen Altertumer von J.Marquardt - Th.Mommsen, Bd.3, 1 Teil, Basel 1952 /Nachdruck 3 Auf1./, 37 i 39 n.1. 
dobnie jak sanskryckie "piter", greckie" $\pi \curvearrowright \tau \eta ́ ; "$ angielskie father, niemieckie Vater itd. pochodzá od sanskryckiego rdzenia "da", który znaczy: bronić, protegować ${ }^{21}$

Podstawowe zatem znaczenie wyrazu "pater" to: protektor, opiekun, obrońca. Wyraz "fllius" wywodzi sie od "fela"/= pierś macierzyńska/ 1 pierwotnie oznaczał dziecko przy piersi22, a więc potrzebujące szczególnej opieki. Dopiero później wyraz "filius" oznaczaz wszystkie dzieci bez różnicy wieku. Stopniowo zanika pierwotne jego znaczenie, ale sens pozostaje.

W tym kontekście myraz "pater" może oznaczać nie tylko opiekuna 1 obrońcę, ale także żywiciela i pracodawcę. Dlatego ojcem nazywano równiez pana oraz opiekuna. Seneka pisze: "maiores nostri /.../ dominum patrem familiae adpellaveruntn23. Do rodziny / familia/ należel1 zatem wszyscy, którym ojciec zapowniał dach nad głową 1 utrzymanie.

Pochodzenie wyrazu "familia" jest niepewne, prawdopodobnie wywodzi sie od oskijskiego "laamat", co znaczy mieszka/habitat, o $\chi x \varepsilon \varepsilon \iota,{ }^{14}$. W tym znaczeniu Seneka pisał: "/.../ maiores nostr1 /.../ appellaverunt, servos, /.../ familiares" 25 .

Slady takiego pierwotnego rozumienia funkeji ojca w rodzinie znajduja sie wrólewskich ustawach. Dionizjos w swych "Starozytnośclach rzymskich" zanotował: "Romulus nałożył na obywateli obowiazek wychowania całego potomstwa płci męskiej oraz córek pierworodnych, zabraniając pozbawiania zycia dzieci przed ukończeniem

21 A. Walde, Lateinisches etymologisches Wørterbuch, Bd.2, He1de1berg 19543, 262-264; Festus Sextus Pompe1us, De verborum signiIlcatu quae supersunt cum Paull epistome, ed. Hallace M.Lindsay, LIpsiae 1913, 280.

22 M.Breal - A.Bailly, Dictionnaire étymologique latin, Paris $1866,8.93$ pod: Filius i 8.88 pod: Pelo; A. Walde, Lateinisches etymologisches Worterbuch, dz.cyt., Bd.1, s.475 pod: felo 18.496 pod: P111us.

23 Seneca, Epistola 47,14, tłum. z 1ac. W.Kornatowski/Lucius Annaeus Seneca, Listy moralne do Lucyliusza, Warszawa $1961 / 156$.

24 M.Breal - A.Ballly, Dictionnaire étymologique latin, dz.cyt., 84 pod: armulus; Th.Mommsen, Romisches Staatsrecht, dz.cyt., 54 n. 1; A. Walde, Lateinisches etymologisches Worterbuch, dzocyt•, Bd.1, 8.206 pod: Panulus.

25 Seneca, Epistola 47, 14, Kornatowski 156. 
lat 3, z wyjatkiem zabicia natychmiast po urodzeniu kalek lub potworkó: te pozwolił ojcom porzucić, jeżeli przedten pokazano je pięciu najbliższym sąsialom i oni to stwierdzili, wobec tych, którzy nie podporządkują sie ustawom niniejszym, król ustalił kary, m.in. i tę, ze połowa ich majatku podlega konfiskacie" ${ }^{26}$.

To prawo królewskie /lex regla/ miało ograniczyć ojcowską madzę nad dziećmi /potestas patria/. Ojciec bowiem posiadał wobec nich prawo źycia i śmierci/lus vitae ac necis/. Ustawa ta odebrała ojcu moźność decydowania o przyjęciu do rodziny lub odrzuceniu niemowlecia/ius tollendi/. Zabroniła porzucania dzieci na równi z zabijaniem. ojciec nie tylko nie mógł zabić potomstwa płc1 męskiej i córek pierworodnych, ale również ich sprzedać. Za czyn zbliżony do zabójstiwa uważano także Rzymie odmówienie płacenia alimentów.

Według ustawy królewskiej ojciec rodziny mógł pozbawić wolnoś$\mathrm{ci}^{27}$ wrasue dzieci obojga płci / filios/ i stosować kary fizyczne wobec dzleci podwładnych /verberatio/, nie mógł ich jednak biczować /Plagris caedere/. Pozbawić życia swolch podwładnych mógł jedynie obecności świadków ${ }^{28}$. Synowi moźna było wyuierzyé sprawiedliwość łącrnie z kara śmierci, nie woilno jednak było dowolnie pozbawiać go życia ${ }^{29}$. Jeśli syn pobil ojca, wówczas, według ustawy Serwiusza Tuliusza, podlegal wyklgciu/sacer esto/30, a ojciec mógł zabić, jeśli miał świadków pobicia siebie. Podobnie w razie ukarania zony śmıercia, mąz musiał zołać jej krewnych 1 przeprowadzić śledztwo w ich obecności ${ }^{31}$. Za czasów królewskich ojeiec

26 Dionysius, Antiquitates Romanae II 15,35-44. Przytaczaria Borysem Lapickim, Waadza ojcowska w starozytnym izymie. Czasy królewskie i republikuńskie, frarszawa 1933, 3; por. A.Kiessling, Dionysii antiquitatum quae supersunt, Parisiis 1886, 8; C.G.Bruns, Fontes iuxis Romani, Bd.1, ed. Th.Mammsen - O.Gradenwitz, Tubingen $1909^{3}, 7$.

27 Dionysius, Antiquitates Romanae II 26,22-26. 0 domowym wiezieniu /ergastulum) wspomina wielu pisarzy lacińskich, np. Cicero, Pro Cluentio 2i; Suetonius, De vita Caesarum. Augustus 32.

28 Livius, Ab urbe condita I 26.

29 Plinius, Historia naturalis XIV 13.

30 C.G.Bruns, Fontes iuris Romani, dz.cyt., 14.

31 Dionysius, Antiquitates lomanae II 25,34-38; A.Kiessling, Dionysil antiquitatum quae supersunt, dz.cyt., 87; Historia naturalis XIV 13. 
nie mógł uwolnić synów spod swej władzy /emancipatio/, ani przekazać władzy nad nimi innemu obywatelowi na zasadzie przysposobienia /adopt1o/. Na wydziedziczenie/exheredatio/ syna musiał uzyskać zgode narodu rzymskiego ${ }^{32}$. Nie dopuszczano także wypędzenia z domu. Nie udowodniona 1 mało prawdopodobna jest kara sprzedazy syna trans Tiberim. Ojcłec mógł tego dokonać jedynie w wypadku skrajnej nędzy dla ratowania całej rodziny 33 .

W okresie republikańskim ustawa królewska o porzucaniu dzieci nie została prawnie uchylona. Ojcowie rodzin zdołali jednak odzyskac swoja pierwotna wadzę. Kontrole nad zyciem rodzinnym i wypeinieniem patriae potestatis przejęli konsulowie, a potem cenzorzy ${ }^{34}$.

Wydaje się rzecza pożyteczna przypomnieć w tym miejscu postawe pisarzy rzymskich wobec problemu porzucania dzieci. Na ogół wszyscy autorzy powołują się na Terencjusza i Plauta. Komedie Terencjusza wzmiankujace o porzucaniu dzieci odzwierciedlaja stosunki i prawo greckie ${ }^{35}$. Plaut trzyma się wzorów greckich i opisuje ich obyczaje, czasami jednak zmienia oryginał grecki i podaje panujace stosunki rzymskie ${ }^{36}$. W dwóch komediach: "Casina" i "Cistellaria" porusza on problem porzucania dzieci. Pierwsza stanowi tłumaczenie greckiej komedii Difilosa 37 , a jej akcja dzieje sie w Atenach. Druga jest tłumaczeniem jednej z komedii Menandra, rozgrywajzcej sie w Grecji, której bohaterami sá równiez Grecy. Przedmiotem komedii saz obyczaje greckie. W obu komediach chodzi o dzieci nieślubne, porzucane przez dziewczęta o zmroku. W "Cistellaria"38 dziewica/virgo/ zgwałcona przez kupca Demifo z Lemnos każe swojemu niewolnikowi dokonać porzucenia /expositio/ dziecka, natomiast w "Casina"39 porzuca dziecko sama kobieta/mulier/. Niewolnik, będac świadkiem całego zdarzenia zabrał dziecko, późniejsz: Kasynę, do domu.

32 B.Lapicki, Mładza ojcowska, dz.cyt., 31-34; por. note 20 .

33 Tamże 48-51.

34 Cicero, In Verrem 2,138: "Censores /.../ lacunam rei Iamiliaris explerent"; por. De republica IV 6; Pro Cluentio 48.

35 G.Glotz, Expositio, art,cyt,, 930 przypis 26.

36 G.Przychocki, Plautus, Kraków 1925, 74-91.

37 Tamże 76 .

38 Plautus, Cistellaria 154-157.

39 Plautus, Casina 41-43. 
L Komeali Plauta nie wynika, aby za jego czasów w iźzyme ojciec rodziny miał prawo porzucania lub zabijania niemowląt. Hówniez Cyceron, który w "De legibus" przypomina przepis ustawy XII tablic o obowiłzku natychmiastowego usunięcia noworodka - potworka, nic nie móri o prawie ojca do usuwania potomstwa zdrowego 40 . Seneka, omawiajac w "Kontrowersjach" wypadek porzucenia dziecka stwierdza, że ojciec może żądać zwrotu podrzutka, jeśli wyrówna koszty jego wychowania ${ }^{41}$. W tymże zbiorze móm sądowych autor podnos1 problem dzieci porzuconych przez ojca a nastepnie znalezionych i tak okaleczonych przez żebraków, że niemożliwych do rozpoznania i odzyskania przez ojca ${ }^{42}$. Wydaje się, że zgodnie z przytoczonymi wypowiedziami, według Seneki, ojciec rodziny nie mial prawa porzucenia /expositio/ dziecka, ale w razie popełnienia tego czynu nie tracił nad nim władzy ojcowskiej/patria potestas/.

Dalsze wiadoności charakteryzujace problem porzucania dzieci w okresie republikańskim odnajdujemy u późniejszych pisarzy, zarówno łacińskich, jak 1 greckich. Liwiusz informuje, że we Fruzynonie przyszło na świat dziecko, które wieku 4 lat nie posiadało "zdecydowanych cech męskich albo niewleścich". Wezwano wrózbitów z Etrurii 1 ci orzekli: "Znak to niemiły i brzydki/foedum ac turpe prodigium/. Nalezy to niemowlę poza terenem rzymsim, z dala od zetisnięcia z ziemia, zatopić w głebi morza. Wsadzono je zywcem do skrzyni, wywieziono na pełne morze $i$ tam zatopionon ${ }^{43}$. Fragment ten świadczy o obowiązku zabijania potworków.

Kasjusz Dio w "Historii rzymskiej" przytacza zdarzenie z 44 r.

40 Cicero, De legibus III 9,19, tłum. z łac. W.Kornatowski /Marcus Tullius Cicero, Pisma fliozoficzne, t.1-4, Warszawa 1960/, t.2, 295:"Mimo że zaraz potem ten szpetny płód został zgładzony niby potworny noworodek zabijany na podstawie prawa dwunastu tablic, w krótkim czasie odrodził sie w jakiś tam sposób i zjawił się w postacl znacznio brzydszej i straszniejszej niż przedtem".

41 Seneca, Controversiae IX 26: "... expositum qui agnoverit solutis alimentis recipiat".

42 Tamże x 33:" .../ expos1tos debilitabat et debilitatos mendicare cogebat /.../ laesi patres ne liberos suos aut agnoscant aut recipiant".

43 Livius, Ab urbe condita XXVII 37, tłum.z łac. M.Brozek/Tytus L1wiusz, Dzieje Hzymu od założenia miasta, Ksiegi XXI-XXVII, Wroctaw 1974/, 389 . 
przed Chr. Ojciec nowo narodzonego syna Attil, siostry Cezara, chciał zabić niemowle pod wpływem przepowiedni Nigidiusza Figula, że będzie ono samowladcaz, ale znawca horoskopów go powstrzymał. ojciec w myśl obowiqzującego prawa/lex Valeria/ chciał zabić przyszłego tyrana. Nie ma więc ten opis nic wspólnego z dowolnym niszczeniem wasnego potomstwa $\mathbf{4}^{4}$. Jeszcze jedna wzmianka o porzuceniu dziecka znajduje sie u Swetoniusza, lecz nie rozstrzyga ona omawianego zagadnienia, ponieważ sprawa, o której mówi autor, rozgrywa się walii, a nie Rzymie ${ }^{45}$.

Przytoczone wypowiedzi pisarzy starozytnych nie daja argumentów do stwierdzenia, ze ojciec rodziny na mocy prawa lub przynajmniej opini publicznej mógł w Hzyie republikańskim zgładzać nor malne dzieci ślubne, które urodziły sie pod dobrymi auspiejami. ¿ówniez w literaturze odnoszącej sie do pryncypatu 1 cesarstwa nie ma dowodów istnienia prawa ojca do porzucania niemowląt. Swetoniusz w żywocie Boskiego Augusta 46 i Pliniusz w liście do Trajana zdaja sia zaprzeczać istnieniu takiogo prawa ${ }^{47}$.

Posiadamy dokumenty literackie świadczq̨ce, że brano w obronę prawnz w okresie republikańskim, bez względu na wole ojca, nie tylko dzieci urodzone, ale już poczęte. Prawo pretorskie przyznalo poczętemu dziecku po śmierci jego ojca ochronę oraz posiadanie majatku 48 . Interesujazca jest w tej materii mowa Cycerona wobronie Aulusa Kluencjusza oskarżonego o otrucie ojczyna oppianika, w której az trzykrotnie porusza sprawe spędzenia płodu. diówca podaje, że oppianik struł swoja brzemienną bratową za życia jej nęża 1 dodaje: $" / . . /$ illud, quod erat ex Pratre conceptum, necaretur" 49 .

44 Tawże II o, tłum. A.Kościbłek/Księgi I-V, Wrocław 1968/84-85.

45 Suetonius, De grammaticis 7; por. Caesar, De bello Gallico VI 19.

46 Suetonius, De vita Caesarum. Augustus 62-65, tium, $z$ łac. J.Ni emirska-Pliszczyńska/Swetoniusz, Żywoty cezarów, Wrocław $1969 \%$ 150-154

47 Plinius, Epistulae X 65/71\%

48 Servius sulpicius, D 37,9,1,24: "cura et bonorum possessio ventris nomine"/Cytuje za B.Lapickin, Władza ojcowska, dz.cyt., $103 \%$

49 Cicero, Pro Cluentio 11,31 . 
/.../ Ceteri non videntur in singulis hominibus multa parricidia suscipere posse, Oppianicus inventus est qui in uno corpore pluris necaret $" 50$. Dla uzasadnienta zbrodni /scelus/ Oppianika powołuje s1e na wypadek, jaki przydarzyl sie w Azji Mniejszej za jego prokonsulatu. Ukarano bowiem wdowę za spędzenie płodu po śmierci męża. Jej czyn uznano za zbrodnie: "rei capitalis esse damnatam"51. 0stry zaś wyrok wyjaśnia następująco: "nec Iniuria, quae spem parentis,memoriam nominis, subsidium generis, horedem familiae, designatum rei publicae civem sustulisset" 52 .

Mówca, powracając do sprawy Oppianika, zarzuca mu nowa zbrodnie, mianowicle zagrabienie dziedzictwa po swoim krewnym /avunculus/ Magiusie, który umierając wielkie dobra zapisał w testamencie swemu dziecku, mającemu przyjść na świat. Tymczasem Oppianik nakłonił wdowe do speqdenia płodu i poślubił ja więć miesięcy po śmierci jej męża. Ich wspólne pożycie nie trwało długo, "ponieważ nie było złączone godnością małżeństwa, lecz zbrodniczym współdziałaniem"53. Cyceron worderstwie dziecka nie narodzonego uwypuklił w szczególny sposób zbrodnicze współdziałanie/societas sceleris/ Oppianika i matki. Mówca ukazal daleko posunięty proces degeneracji i deworalizacj 1 warstw posiadających 1 łamanie obowiłzzujących ustaw w okresie republikańskim 54 .

Liwiusz podaje, że już za czasów republiki przyjęła się ogólna zasada: "patrem sequuntur liberi"55. Przynależność do rodziny określało zatem ślubne pochodzenie dziecka. Uznanie dziecka przez ojca 1 przyjęcie go do rodziny/tollere et suscipere/liberum/utraciło swoje pierwotne znaczenie, zachowując jedynie role symbolu.

W omawianym okresie na ojcu ciąży nie tylko obowizzek przyjącia dziecka, lecz także utrzymania go $i$ wychowania ${ }^{56}$. Hychowanie miało

50 Cicero, Pro Cluentio $11,32$.

51 Tamże.

52 Tamze.

53 Tamże 12,35: "Erant enim non matrimonii dignitate, sed sceleris societate coniunctae".

54 Por. K.Kumaniecki, LIteratura rzyiska. Okres cyceroński, Warszava 1977, 219-220.

55 Livius. Ab urbe condita IV 4.

56 Cicero, In Verrem 3,69: "eos instituere et erudire /.../ debuisti"; por. tenże, Brutus 58; De republica 2,34. 
na celu ukształtowanie człowieka pod względem moralnym i prawnym /Inst1tuere/. Chodziło o wpojenie dzieciom czystości moralnej/pudicitia, castitas/, uczciwości i wierności. Wdrażano dzieciom przepisy prawa $i$ wszczepiano religie przodków. Wychowanie polegało równiez na kształceniu /erudire/ dzieci i młodzieży. Uczono ich mowy ojczystej, przekazywano wszystkio podstawowe wiadomości potrzebne do życia. Oprócz tego przygotowywano młodziez do konkretnych zawodów i dziedzin życia społecznego i państwowego, przysposabiano do źycia gospodarczego, politycznego $i$ wojskowego 57 . W procesio wychowania nowego pokolenia Rzymian rodzice spełniali pierwszorzęna role. Władza ojcowska była ograniczona wówczas, kiedy w gre wchodziło nakłanianie dzieci do złych czynów. Syn miał wówczas nio tylko prawo, ale nawet obowiązek odmówienia ojcu pozłuszeństwa. Seneka retor na pytanie: czy we wszystkich sprawach należy ojcu okazywać posłuszeństwo, odpowiada przecząco, kiedy chodzi o przekazanie syna w adopcje i kiedy ojciec każe go zabić, bo tego prawo zakazuje ${ }^{58}$. Powyższa zasada miała zastosowanio w konkretnych przypadkach. 0jca, który czerpal zysk z prostytucji swoich dzieci/lenocinium/59 uwazali pretorzy za niegodnego czci i miał on ograniczone zdolności procesowe. Przestepstwo to stanowiło według prawa julijskiego/lex Iulia municipalis/ dostateczny powód przeniesienia go do niższej klasy obywateli 1 skreślenia z listy senatorów/senatu movere/60. Zgromadzenie narodowe skazało na kare chłosty/supplicium fustuarium/ trybuna ludu Skantyniusza Kapitolina za uprawianie nierządu /stuprum/ z własnym synem ${ }^{61}$. Katon, pełniac funkcje cenzora, skreślił z listy senatorów ojca, który w obecności córki dziewicy uścisnaz swoja zonę ${ }^{62}$. Cyceron oskarzył Werresa o popełnienie bezprawia/inluria/ wobec swego syna w wieku młodzieńczym na Sycyll1, ponieważ

57 if.J.Marrou, Histor ia wychowania w starożytności, tłum. z franc. S.Los, Warszawa 1969, 325-435.

58 Seneca, Controversiae I 1, 1 .

59 Th.Mommsen, aØmisches Strafrecht. Systematisches Handbuch der llechtswissenschaft, 4 Teil, 1. Abtellung, hrsg. K. Binding, Graz 1955 /Nachdruck der 1889 Verlag/, 699.

60 Th.Mommsen, RUmisches Staatsrecht, dz.cyt., Bd.2, 1. Teil, 383; C.G.Bruns, Fontes iuris Homani, dz.cyt., 108-109.

61 Por. Th. Mommsen, nUmisches Strafrecht, dz.cyt,, 984 nota 2; C.G. Bruns, Fontes luris comani, dz.cyt., 109.

62 Plutarchus, Vitae parallelae. Cato 17. 
pozwoliz mu przypatrywać sie rozpuście/voluptas/ 1 haniebnym czynom / Plagltia et turpitudines/63. Mówca rzymski utrzymuje, ze rodzina stanow "zaczątek miasta 1 jak gdyby zalażek państwa"64. dziecl zaś naleźa nie tylko do ojca rodziny, ale i do państwa. Wobec tego wychowanie dzieci winno uwzględnic równiez dobro państwa rzymskiego ${ }^{65}$. Jeśli wychowanie dzieci nie jest zgodne z interesami państwa rzymskiego, ojciec postępuje niesprawiedliwie wobec ojczyzny ${ }^{6}$. Reasumujac moźna stwierdzić, że do zadań ojca rodziny w okresie republiki nalezało utrzymante 1 wychowanie dzleci zgodnie z podstawowymi zasadami ustroju, moralności /boni mores/ $i$ dobrem państwa rzymskiego.

Z ojcowskich zadań 1 uprawnień zasługuje na uwage religijna wradza ojca jako głowy kultu domowego. Za jej istnieniem przemawiają względy językowe i prawno-historyczne. Wyraz ojciec/pater/ odnoszono do bogów rzymskich i do ojca rodziny 67 . Jowisza nazywano ojcem bogów i ludzi /pater deorum hominumque/. Sam wyraz Jupitor mógł brzmieć pierwotnie Jupater albo, jak utrzymuje Jan Parandowski, Diovis pator 68 . Ojciec rodziny po śmierci byl ubóstwiany i czczony jako opiekun ogniska domowego 69 . Za swego zycia by głowa kultu domowego, do niego nalezało odmawianie modłów i składanie ofiar/sacra privata/. Kierował obrzedami pogrzebowymi i czuwał nad przestrzeganiem przez rodzinż okrosu żałoby /tempus lugendi/. W testamencie mlanował następce, któremu przekazywal opiekę nad sacra privata 1 środki materialne konieczne na ten cel

Rola ojca $w$ rodzinie, jak to podkreślano, by za zasadnicza. Nienniej waźne było równiez powołanie natki. lzymianka wprawdzie

63 Cicero, in Verrem 2,3,69.

64 Cicero, De officiis 1, 17,54 : "principium urbis et quasi seminarium rei publicae", tkum.W.Kornatowski t.2, 356.

65 Cicero, In Verren 3,59: "/../ usui rei publicae esse possunt. Eos instituere atque erudire ad matorea instituta atque civitatis disciplinam /.../ debuisti"; por. tenże, De inibus bonorum et maiorum 1,7,24, Kornatowski t.3,176.

66 Cicero; In Verrem 3,69: "rei publicae fecisti iniuriam".

67 A. Walde, Lateinisches etymologisches Worterbuch, dz.cyt., Bd.2, s.262 pod: pater.

68 J.Parandowski, Mitologia, Warszawa 1975,62.

69 G.Wissowa, Re 1 igi on und Kultus ler homer. Munchen $1912^{2}, 234,238$. 
nie posiadała, jak knbieta grecka, praw obywatel skich, była bowiem odsunięta od spraw państwowych ze względu na wrodzona wstydliwośc /pudicitia/, słabość /infirmitas, fragilitas/ i nieznajomość praw publicznych /forensium rerum ignorantia/. Korzystała jednak z większej swobody niż Greczynki okresu klasycznego. Wychodząc za mąz przechodziła spod wadzy ojca lub opiekuna pod władze męza. W nowej rodzinie zajmowała miejsce córki/filiae famillas loco/. Mąż nie miał nad nią prawa życia i śmierci, nie mógł jej równiez ani sprzedać, ani oddać pod władzę innego. Mogła ona sama zerwać małżeństwo przez rozwód. W rodzinie zajnowała godne stanowisko, była gospodynia /domina/ domu. Zarzadzała gospodarstwem domowym, towarzyszyła mezzowi w jego zajeciach, wraz z nim troszczyła sie o sprawy rodziny, dozorowała służbę domowa, pielęgnowała i wychowywała dziec1, brała udział w życiu towarzyskim, bywała na przyjęciach i ucztach, cow Grecji było niedopuszczalne. Jej zależność od ojca czy męża ograniczała sie zasadniczo do spraw majatkowych. Z biegiem czasu sytuacja w tej dziodzinie uległa polepszeniu, gdyż zdobyła ona prawo wyboru opiekuna do spraw majątkowych, a nawet sama mogła rozporzadzać posagiem przy ponocy mądrego niewolnika/servus dotalis, atriensis/70.

Rzymianie wysoko cenili rodzinez $i$, aby zapewnić jej ciagłość i nienaruszalnośc, szczególniz opiekaz otoczyli małźeństwo. 0 wyborze męza, podobnie jak w Grecji, decydował ojciec córki w porozumieniu z ojcern przyszłego zięcia. Mężcyzna mógł zawrzeć małżéstwo już w 14, a kobieta w 12 roku życia. kzymianie rozróżniali prawny zwiazek małżéski /matrimonium iustum/i nieprawny /matrimonium iniustum/. Watrimonium iustum mogło być zawarte tylko między osobami równego stanu, posiadajazcymi ius connubii.Prawo takie posiadali patrycjusze. Ustawa Kanulejusza /lex Canuleia/ z 445 r. prz. Chr. zniosła różnice stanów. Odtąd warunkiem do zawarcia prawnego małżeństra było rzymskie obywatelstwo. Brak tego warunku czyniło

70 Dobry wybór tekstów autorów greckich i rzymskich o starożytnej kobiecie opracowała, wstepami i komentarzem opatrzyła L. Winniczuk: Kobiety swiata antycznego, Warszawa 1973, oraz: Słowo jest cieniem czynu czyli starozytni Grecy i fzymianie o sobie, Warszawa 1972, 164-198/świat kobiet i rodzina/. 
małżeństwo nieprawnym. W lizymie istniały dwie prawne formy zawierania małzeństw. Pierwsza była połłczona z przejściem zony pod władzę męa /conventio in wanum/ $i$ przyjøeiem jej przez rodzinę męza. Manus oznaczało przywileje, które prawo przyznało głowie rodu. if drugiej formie zaślubin zona pozostawała nadal pod władzá ojca /in potestate patris, sine conventione in manum/. Dawała ona mezzw1 dzieci, ale sama nie podlegała jego wadzy. Podstawe prawnaz stanow1ło obustronne wyrażente zgody na współżycie małżenskie/affectio maritalis/.

Małżéstwo ścisłe /cum conventione in manum/ mogło być zawarte według jednej z trzech form. Pierwsza z nich było symboliczne kupno/coemptio/ dziewczyny, która jednak musiała wyrazić na nie zgode. Po raz ostatni o tej formie słyszymy w czasach Tyberiusza. Druga forme stanowiło korzystanie z praw małzeńskich/usus/. Polegało ono na rocznym wspólnym zainieszkaniu kobiety z mężczyzną, - ile 3 kolejnych nocy nie spedziła kobieta poza domem. Według prawa zwyczajowego po takim rocznym wspólnym życlu stawali sie małżonkami. Po 445 r. prz. Chr. taka forma zawarcia małzeństwa stała sie przeźtkiem. Całkowicie zlikwidował ja cesarz August. Trzecia forma zaślubin/confarreatio/, oprócz podstaw prawnych miała charakter religijny i najbardziej uroczysty. Jowiszowi o przydomku Farreus /opiekun zboża/ składano w ofierze placek z orkiszu/panis farreus/, który spożywali nowożeńcy 1 goście weselni.

Właściwy akt małzeństwa poprzedzały zaręczyny /sponsalia/, które polegały na słownym przyrzeczeniu. Wprawdzie o wyborze mezza decydował ojciec córki, ale istnieje zasadnicza różntca w wyrazeniu zgody na małżeństwo dziewczyny Grecji $i$ Rzymio. Grecjl czynił to wimieniu córki jej ojciec, a jeśli nie miała ojca, to opiekun. W Rzymio narzeczona sama odpowiadała narzeczonemu na postawione pytanie: spondesne-spondeo.

Sam przebieg obrzęu małzeństwa był bardzo uroczysty. W przeddzień ślubu dzlewczyna zdejmowała swe dziewicze szaty/toga praetexta/ a wdziowała stosowna nowemu stanowi czysta, blala toge, prosta długa suknie /togam puram/, równo opadajaca /tunicam rectam/. Toge przepasywała paskiem. Krótki,ognistego/flammeum/lub szafranowego/cròceum/ koloru welon na głowie osłanial częściowo jej 就y, policzki $i$ ramiona. Uroczystość zaślubın/nuptiae/ rozpoczynała się od wrózb z lotu ptaków lub z wętrzności zwierząt, po 
czym składano ofiarę z owcy lub kozy, zwierząt poświęconych bóstwom ziemt 1 płodnośc1, Cererze i Tellus oraz mznoszono modły do bóstw oplekujących się małzeństwami. Po tych religijnych przeżyciach następowała uczta /cena nuptialis/w domu panny młodej. Do zebranych gości wprowadzała pannę młodą starościna weselna/pronuba/. Mogła nią być kobieta cieszaca sie wielkim powazaniem i dochowująca wierności mężowi przez całe życie/univira/71. Ona towarzyszyła pannie młodej przy wróżbach, oddawała ją przyszłemu mézowi przez złazczenie ich dłoni/dextrarum iunctio/. Piękny to symbol rspólności życia małzonków, który trwa wie zmienionej formie w liturgii katolickiej. Po uczcie późnym wieczoren lub nocą nastepowało przeprowadzenie narzeczonej w uroczystym pocinodzie do domu jej przyszłego męża/deductio domum/. Na czele pochodu kroczył szczęśliwy chłopiec/patrimus et matrimus/, niosacy pochodniez tarniny /spina alba/. Za nim dwaj nieosieroceni chłopcy prowadzili panne młodą ${ }^{72}$, a za nimi niesiono symbole pracy domowej, wreszcie szła rodzina, przyjaciele, znajomi i inni. Pochodowi towarzyszyz śplew 1 muzyka. Dowcipne przyśpiewki / fescenninae/ uprzyjemniały pochód. Narzeczony, czekający za progiem, witał serdecznie swa przyszłą zonę, a ona wymawiała "sakramentalne" słowa: "Ubi tu Caius, ibi ego Caia"73, którymi myrażała wszystko, co można powiedzié - małżeństwie. Lączyła się ze swym mężem na dolę 1 niedole, na życie ziemskie $i$ państwie cieniów groźnej Prozerpiny. Po wypowiedzeniu formuły: "Gdzie ty Gajusie, tam ja Gaja", namaszczała tłuszczem wieprza lub wilka drzwi domu, do którego wchodziła jako przyszła mater familias 1 ozdabiała je wstzżkami/wieprz by zwierzeciem poświęconym Cererze, a wilk - Marsowi/. Przez próg domu młoda

71 Festus Sextus Pompeius, De Verborum significatu, dz.cyt., 283: "Pronubae adhibentur nuptis, quae semel nupserunt, causa auspicii, ut singulare perseveret natrimonium".

72 Tamze: "Patrimi et matrimi pueri tres adhibebantur in nuptiis, unus, qui facem praeferret ex spina alba, quia noctu nubebant, duo, qui nubentem tenebant".

73 Plutarchus, Quaestiones Komanae 30. 
zonę przenosili chłopcy, a mąz witał ja u wejścia woda i ogniem. Foda była 3ymbolem jozyszczenia, zaś ogień oznaczał wspólne ognisko domowe, na którego straźy stała mater familias. W końcu pronuba mpronadzała młoda zonę do atrium, gdzie przyszła mater familias polecała wraz ze swym męzem sprawy zaczątkowej rodziny opiekuńczemu bóstwu, Gentuszowi. Następnego dnia odbywały sie poprawiny/repotia/, składano oflary bogom i ucztowano.

Wnikając głębiej sedno samej formy małzeńskiej, moźna dojść do przekonania, ze Rzymianie waśnie nierozerwalności losów dwojga ludzi zdecydowanych na wspólne życie widzieli jedynz moralna zasade zwiqzzku męzczyzny z kobieta 1 etyczne prawo, które uświęca monogamie.

W okresie cesarstwa wastępstwie ogólnego rozluźnienia obyczajów, kobiety korzystały z coraz większych swobód. Ojcowie nie wybierali już córkom męźó, mogły teź one same rozporządzać swoim majątkiem. Taki stan rzeczy doprowadził do rozwodów. Podobno pierwszy rozwód miaz miejsce w 231 r. prz. Chr. Pod koniec Rzeczypospolitej rozwody stały sie zjawiskiem powszechnym. Przyczyny rozwodów były różne: poważne, jak zdrada żony, ale często błahe, np. myjście zony na ulice z odsłoniętą twarziz. Horacy domagał się od Augusta obrony zagrożonych obyczajów, jeżeli życzeniem cosarza było wyrycie na jego pomniku tytułu ojca ojczyzny ${ }^{74}$. Pod naciskiem oplnil publicznej przywrócił on prawa jullańskie 1 wydał nowe, zwane lex Papia Poppaea, które godziły wezzennych. Prawa zaś jullańskie miały zapobiegać manil rozwodów przez utrudnianie zrywania małzeństwa ${ }^{75}$. W ten sposób Rzym bronił wielkości podstawowej komórki społecznej państwa 1 świętości ogniska domowego. Rzymianın wysoko cenił zycie rodzinne, a matke uznał za świętośc najwi ższą, jaką posiada na świecie, miłościa jednoczącą ze sobą rodzinę, społeczeństwo 1 naród ${ }^{76}$. Symbolem tych uczuć jest wspaniałe mauzoleum,

74 Carmina III 27.

75 N.Cal1, Sulla legislatione matrimoniale di Cesare Augusto, "Annuario dello Istituto di storia del diritto romano di Universitá di Catania" 1/1891/16-18.

76 Por. L:H.Morstin, V kraju Látynów, Viarszawa 1956, 154-197/Laus Peminae/. 
cylindryczny grobowlec o średnicy 20 metrów, zbudowany przy v1\& Appia Antica przez Quintusa Metellusa I . pra. Chr. dia a córki - Cecyl11 Metel11. Ta domina lomana zasłaryla sobie na diugam wiecznz pamié, gdyz byla dobra zona, a jej stawa stala sle róra alaw lo królow, konsulów, cesarzy. Plolgrzym odwledzający wioczno Miasto na równi z innymi zna jej niezapomniane irele.

Zbierając główne mýlil o starozytnoj rodzinie rzyagklej, nalozy stwierdzić,że rzymska rodzina przedchrześcijańska by 1 a patrarchalaa 1 monogamiczna. Opierała sie na zasadach prawnch. Wej skiad chom dz111: ojciec, matka, synowie 1 córki niezamęzne, zony i dzlect syn.6w, niewolnicy oraz córki męzatki, które zamariy mazzeństwo bez przejścla pod wadze męza. Głowa rodziny by ojoiec 1 tylko on nie by 1 od nikogo zalezny. Pozostall członkowie rodziny byli pod jego madza. Wradza ojca była potrójna: nad zoną, dziocmi 1 niewolnikar. Wobec dzieci pradawnej rodzinie mial prawo zycia 1 baierci. Tego prawa pozbawiono ojca w okresie królewskim. Nie posladaz go rómnioz w późniejszych czasach: republiki, pryncypatu i cesarstæa. W okresie ropubliki ojciec miat obowlazek utrzymania i mychomanda dziecl zgodnie $z$ zasadami ustroju i morainości oraz dia dobra narodu. Newolników traktowano na równi z rzeczą martwa. Waściciel móg r równiez wyzwolic niewolnika spod swej wadzy. Na ojcu rodziny spoczyła te lunkcja sprawowania religijnego kultu domowego. Zona byla podporzedo kowana mezzowi, ale nie byla jego niewolnica, lecz towarzyszka fycia

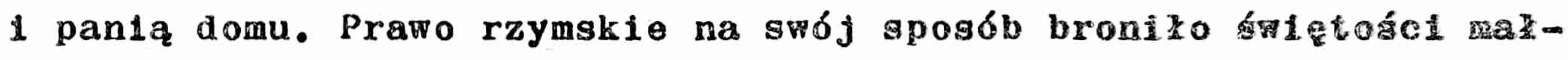
zeństwa, zycia zdrowych nismowlat, takze bralo w ochrone dziecl wonjo matki, zapowniajac im posiadanie majatku po smierel ojca. iv ten sposób niejako przygotowywato rodzine rzymska na przyjecle chrześcijańsiwa.

$$
\text { Ks. Augustyn Eckmarn - Lublin }
$$

\section{DE ANTIQUA FAMILIA GRAECA ET ROMANA} /Argumentum/

Familia Graeca, quae patriarchalis fuit, ex patre, matre, libem ris et iamulis constabat. Pater Pamilas domedominus, tutela Pamillae gerebat atque praesidio ei pult. Femina ut usor v1rl socia pult atque ut mater rem familiarem administrabat ot liberos aducabat. Honor herae domt futt, sed in vita publica nullo sure gaudelet. Ut. Pamilia Graeca sic et Pamilia Romana patriarchalis futt. Romant sum. 
gulas uxores habebant. Familia Romana ex patre, matre, filits, filiabus non nuptis, flilorum uxoribus et liberis, servis, fillis nuptis, quae connubium sine conventione in manum inierunt, constabat. Pater familias caput familiae fuit atque solus sul luris fuit, ceteri familiares alieno iuri subiecti fuerunt. Potestas patris triplex fu1t: manus, patria et dominica. Antiquissimis temporibus pater familias lus vitae ac necis erga liberos habebat. Quo lure tempore regum privatus est, temporibus autem posterioribus hoc ius iam non recuperavit. Tempore rei publicae pater familias officium alendi atque instituendi et erudiendi liberos secundum mores civitatis et bonum commune populi Romani habebat. Servi res habiti sunt. Dominus servum tamen manumittere potuit. Cum uxor subdita viro esset, non serva eius, sed socia vitae et mator fanilias fuit. Lex Romana sanctimoniam connubii, infantes sanos sub bonis auspicils natos atque fetum in ventre matris defendebat et eo modo familiam Romanam ad religionem christianam accipiendam praeparavit. 